\title{
PENGGUNAAN SNI 1726-2019 UNTUK MENENTUKAN BEBAN GEMPA SEISMIK DI KALIMANTAN SELATAN
}

\author{
Eka Purnamasari \\ Dosen Prodi Teknik Sipil, Fakultas Teknik, \\ Universitas Islam Kalimantan MAB. \\ E-mail: eka.ftsuniska@gmail.com/HP.081257303768
}

\begin{abstract}
ABSTRAK
Pada Pulau Kalimantan terdapat tiga zona sesar utama sesar yaitu sesar Tarakan, sesar Mangkalihat, dan sesar Meratus. Ketiga sesar tersebut memiliki panjang lebih dari pada $100 \mathrm{~km}$ yang dapat berpotensi menimbulkan gempa sampai dengan magnitudo 7. Peraturan Gempa Indonesia, SNI 1726:2019, disusun berdasarkan Peta Gempa Indonesia 2017 dan ASCE 7-16. Maka dipilih 13 kota besar di Kalimantan Selatan yang berada dizona gempa yang berbeda dan sesuai dengan Peta Gempa Indonesia 2017. Nilai Koefisien Situs mempengaruhi besarnya Spektrum Respons Desain dan Kategori Desain Seismik. Berdasarkan Percepatan Spektrum Respons pendek MCER pada peta gempa 2017, daerah Kalimantan Selatan termasuk dalam daerah yang memiliki percepatan spektrum Ss dari $0,05 \mathrm{~g}$ sampai dengan $0,4 \mathrm{~g}$. Nilai percepatan spektrum pendek terbesar berada di daerah pegunungan meratus dan sekitarnya. Berdasarkan perbandingan kategori Desain Seismik didapati daerah yang rawan terhadap gempa yaitu daerah Kalimantan Selatan yang berada pada jenis Tanah Sedang (SD) dan Tanah Lunak (SE). Berdasarkan fungsi bangunan dan kelas situs, struktur yang termasuk kategori resiko IV berada di situs tanah lunak yang dikategorikan ke dalam KDS D yaitu bangunan yang digunakan oleh khalayak ramai seperti rumah ibadah, kantor, fasilitas pendidikan, fasilitas kesehatan dan lain-lain.
\end{abstract}

\section{Kata Kunci: SNI 1726:2019, Gempa, Desain, Seismik, Kalimantan Selatan}

\section{ABSTRACT}

Based on the acceleration Response spectrum of 0.2 seconds MCER on a map of earthquake 2017 South Kalimantan, including in the area of acceleration spectrum Ss from 0, $05 \mathrm{~g}$ up to $0,4 \mathrm{~g}$. Where the value of Ss largest meratus mountain area and its surroundings. Based on a comparison of Seismic Design category of the SDS and SD1 obtained against earthquake-prone areas, namely South Kalimantan who are in class Are Land site (SD) and soft soil (SE). Based on the function of building and site classes, structures with high earthquake risk levels most were in soft soil sites are categorized into KDS D i.e. buildings used by audiences such as shops, offices, schools and others. On the island of Borneo, there are three main fault zones, namely the Tarakan fault, Mangkalihat fault and Meratus fault. The three faults have a length of more than $100 \mathrm{~km}$ which can potentially cause earthquakes of up to magnitude 7. Indonesian Earthquake Regulations, SNI 1726: 2019, are prepared based on the 2017 Indonesia Earthquake Map and ASCE 7-16. Then 13 major cities in South Kalimantan were 
selected which were in different earthquake zones and according to the 2017 Indonesia Earthquake Map. The value of Fa and Fv Site Coefficients affects the magnitude of the Design Response Spectrum and the Seismic Design Category. Based on the short MCER Response Spectrum Acceleration on the 2017 earthquake map, the South Kalimantan area is included in an area that has an acceleration spectrum of Ss from $0.05 \mathrm{~g}$ to $0.4 \mathrm{~g}$. The largest value of $\mathrm{Ss}$ is in the Meratus mountain area and its surroundings. Based on the comparison of the Seismic Design category, it is found that areas prone to earthquakes are South Kalimantan which are in the Medium Soil (SD) and Soft Soil (SE) types. Based on the function of the building and the class of the site, the structures that are categorized as risk category IV are on soft ground sites which are categorized into KDS D, namely buildings used by the general public such as houses of worship, offices, educational facilities, health facilities and others.

\section{Keywords: SNI 1726: 2019, Earthquake, Design, Seismic, South Kalimantan}

\section{PENDAHULUAN}

Kalimantan adalah daerah negara Indonesia yang memiliki seismisitas paling rendah, dimana seismisitas lebih didominasi oleh aktivitas dari sesar dengan panjang kedalaman gempa kurang dari $30 \mathrm{~km}$. di Tarakan pada tanggal 20 Desember 2015 Terjadi gempa dengan magnitudo 6 yang berdasarkan solusi GCMT diakibatkan oleh aktivitas sesar geser.

Pada Pulau Kalimantan terdapat tiga zona sesar utama sesar yaitu sesar Tarakan, sesar Mangkalihat, dan sesar Meratus. Pada bagian utara pulau yang terbentang mulai dari daratan sampai menerus ke lepas pantai dikenali sebagai Sesar mendatar Tarakan. Sesar Mangkalihat yang berupa sesar mendatar, diidentifikasi di pantai timur Pulau Kalimantan. Pada bagian selatan Pulau Kalimantan yang disebut juga Zona sesar anjak, yaitu Sesar Meratus dengan arah NE-SW. Semua sesar tersebut memiliki panjang lebih dari $100 \mathrm{~km}$ dan dapat berpotensi menimbulkan gempa dengan magnitudo 7. Gempa ini diikuti oleh aftershock dengan magnitudo mencapai lebih dari 4 yang juga diakibatkan oleh aktivitas sesar geser seperti pada gambar 2. Selain itu, juga terjadi gempa dengan magnitudo 5,1 pada tanggal 24 Juni 2016 pada barat daya Kalimantan yang juga diakibatkan sesar di darat (Peta Gempa 2017,2018).

Dipilihlah tiga belas kota yang dianggap dapat mewakili seluruh wilayah Kalimantan Selatan sebagai sampel untuk memperlihatkan sejauh mana perbedaan spektrum respons desainnya menurut SNI 1726:2019. Selanjutnya, penelitian ini juga menyampaikan pengamatan kategori desain seismik terhadap kondisi spektrum respons desain untuk perioda pendek 0,2 detik dan 1 detik pada peta gempa 2017 sesuai dengan beberapa jenis tanah. 


\section{METODOLOGI PENELITIAN}

Proses perhitungan dan pembuatan Spektrum Respons Desain menurut SNI 1726:2019 adalah sederhana. Dari pemetaan gempa untuk perioda pendek 0,2 detik dan perioda 1-detik, maka dihasilkan nilai percepatan respons spektral perioda pendek 0,2 detik dan perioda 1-detik. Kemudian nilai tersebut dikalikan dengan faktor amplifikasi seismik Fa dan Fv untuk dapat menghasilkan nilai parameter percepatan respons spektral yang sesuai dengan masing-masing jenis kelas situs tanah, $\mathrm{SM}_{\mathrm{S}}$ dan $\mathrm{SM}_{1}$. Besarnya percepatan respons spektral desain pada perioda pendek, perioda pendek 0,2 detik dan perioda 1-detik, adalah 2/3 dari nilai $\mathrm{SM}_{\mathrm{S}}$ dan $\mathrm{SM}_{1}$.

Sesuai dengan ketentuan, peta percepatan spektrum respons gempa maksimum yang dipertimbangkan berbasis pada risiko (MCER) dengan redaman 5\% dan kriteria 1\% kemungkinan bangunan runtuh dalam 50 tahun, yang telah disesuaikan untuk kelas situs tanah antara SB dan SC, untuk perioda pendek (0.2 detik) dan perioda 1-detik, yang diperlihatkan dalam Gambar 1 dan 2, dikembangkan berdasarkan peta hazard dengan probabilitas terlampaui $2 \%$ dalam 50 tahun (perioda ulang gempa 2,475 tahun) yang disusun oleh Tim Pusat Studi Gempa Nasional dalam Peta Sumber dan Bahaya Gempa. Tahun 2017.

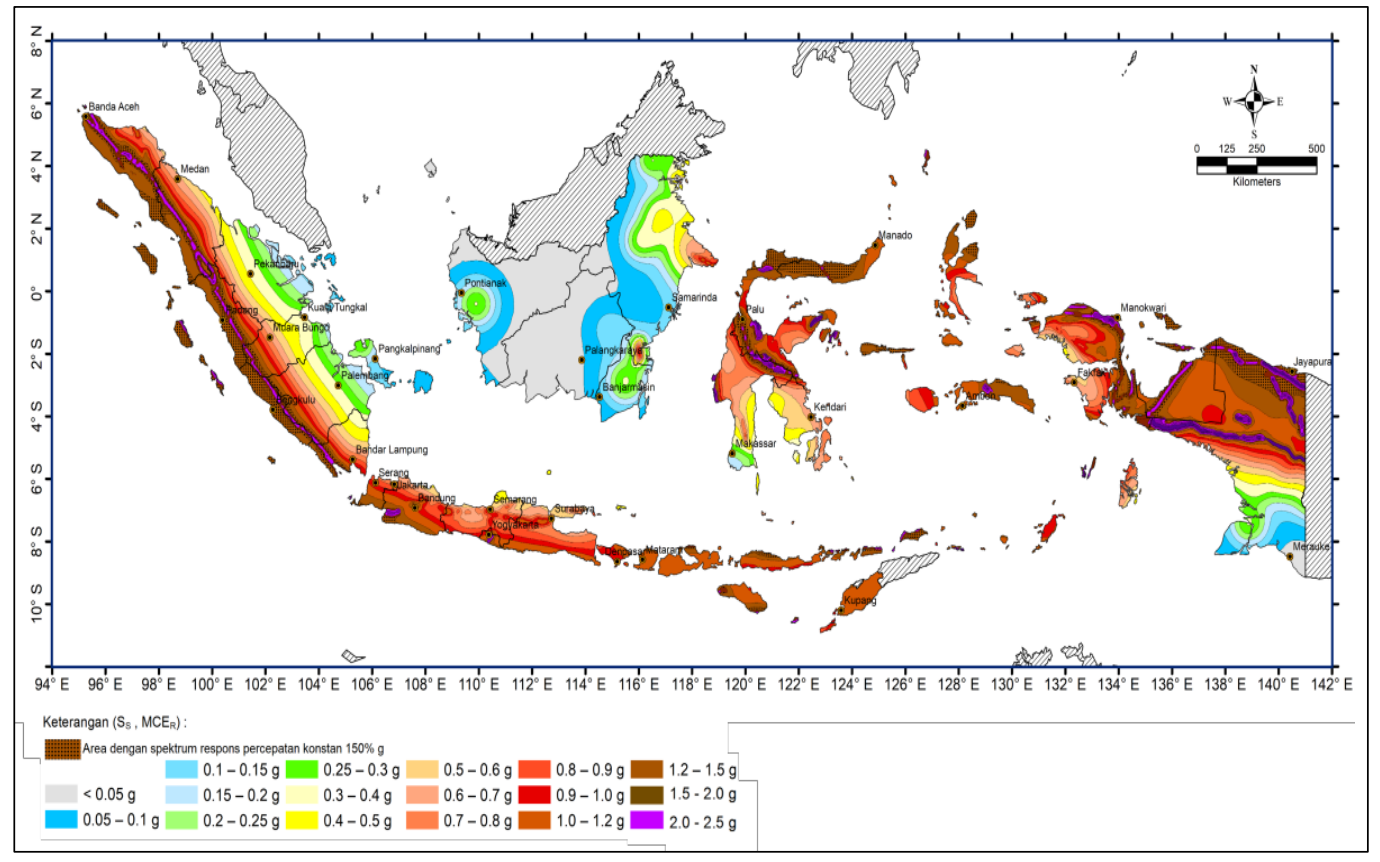

Gambar 1 Peta Percepatan Spektrum Respons 0.2 detik 


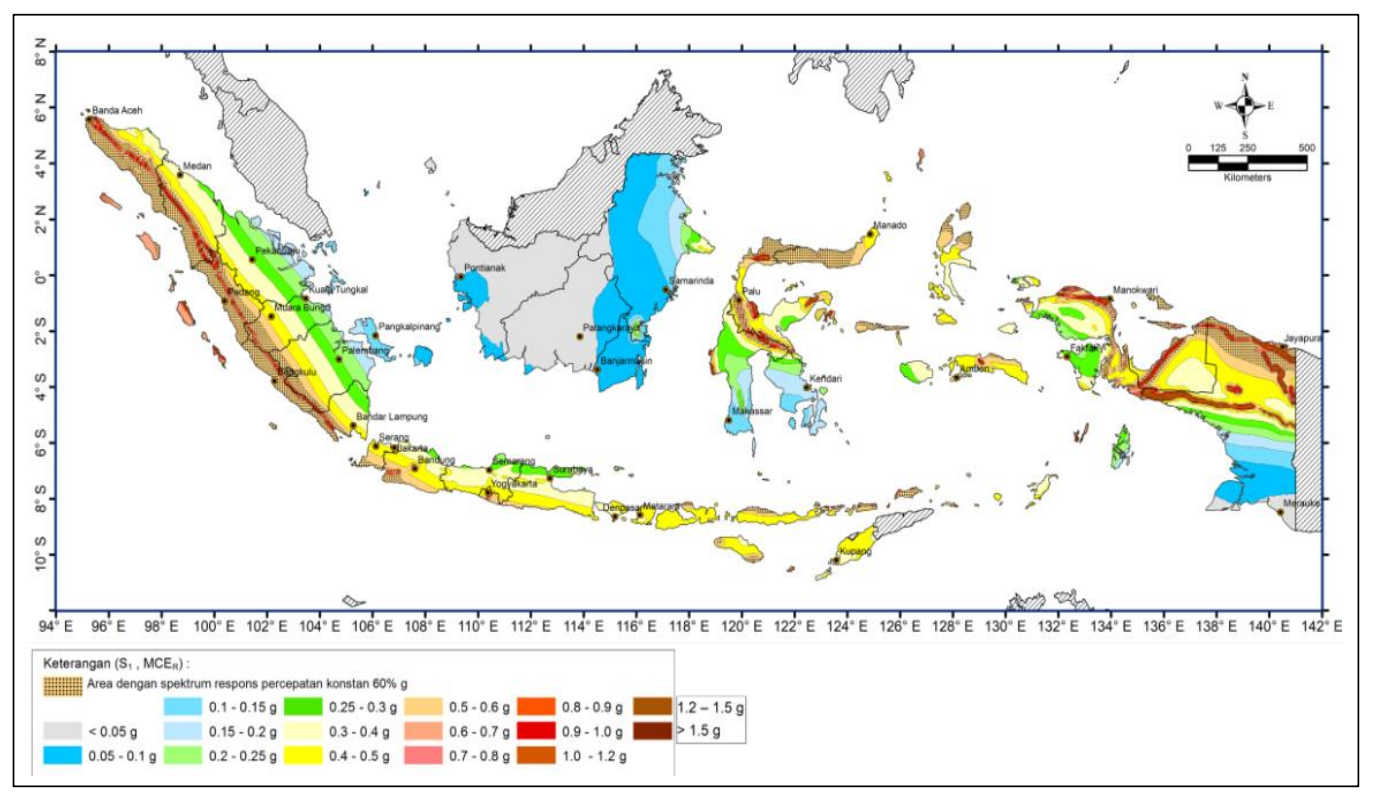

Gambar 2. Peta Percepatan Spektrum Respons 1-detik

Nilai koefisien situs $F_{a}$ dan $F_{v}$ dalam SNI 1726:2019, seperti yang diperlihatkan dalam Tabel 1 dan Tabel 2.

Tabel 1 Koefisien Situs $F_{a}$

\begin{tabular}{|c|c|c|c|c|c|c|}
\hline \multirow{2}{*}{$\begin{array}{c}\text { Kelas } \\
\text { Situs }\end{array}$} & \multicolumn{6}{|c|}{ Param e te r Pe rce patan Re s pons Spe k tral M CER pada Pe rioda Pe nde k (0.2 } \\
& $S_{S} \leq 0.25$ & $S_{S}=0.5$ & $S_{S}=0.75$ & $S_{S}=1.00$ & $S_{S}=1.25$ & $S_{S} \geq 1.5$ \\
\hline SA & 0,8 & 0,8 & 0,8 & 0,8 & 0,8 & 0,8 \\
\hline SB & 0,9 & 0,9 & 0,9 & 0,9 & 0,9 & 0,9 \\
\hline SC & 1,3 & 1,3 & 1,2 & 1,2 & 1,2 & 1,2 \\
\hline SD & 1,6 & 1,4 & 1,2 & 1,1 & 1 & 1 \\
\hline SE & 2,4 & 1,7 & 1,3 & 1,1 & 0,9 & 0,8 \\
\hline SF & \multicolumn{7}{|c|}{$S_{S^{(a)}}$} \\
\hline
\end{tabular}

Tabel 2 Koefisien Situs $F_{v}$

\begin{tabular}{|c|c|c|c|c|c|c|}
\hline \multirow{2}{*}{$\begin{array}{c}\text { Kelas } \\
\text { Situs }\end{array}$} & \multicolumn{6}{|c|}{ Param e te r Pe rce patan Re s pons Spe k tral M CER pada Pe rioda 1 detik } \\
\cline { 2 - 7 } & $S_{1} \leq 0.1$ & $S_{1}=0.2$ & $S_{1}=0.3$ & $S_{1}=0.4$ & $S_{1}=0.5$ & $S_{I} \geq 0.6$ \\
\hline SA & 0,8 & 0,8 & 0,8 & 0,8 & 0,8 & 0,8 \\
\hline SB & 0,8 & 0,8 & 0,8 & 0,8 & 0,8 & 0,8 \\
\hline SC & 1,5 & 1,5 & 1,5 & 1,5 & 1,5 & 1,4 \\
\hline SD & 2,4 & 2,2 & 2 & 1,9 & 1,8 & 1,7 \\
\hline SE & 4,2 & 3,3 & 2,8 & 2,4 & 2,2 & 2 \\
\hline SF & \multicolumn{7}{|c|}{$S_{S^{(a)}}$} \\
\hline
\end{tabular}




\section{HASIL \& PEMBAHASAN}

Dilihat dari peta percepatan batuan dasar periode pendek 0,2 detik (Ss), untuk ketiga belas daerah terpilih pada provinsi Kalimantan Selatan terbagi menjadi 6 (enam) daerah spektrum gempa yaitu nilai $\mathrm{S}_{\mathrm{S}}$ berkisar dari 0,05g sampai dengan 0,4g. Dilihat Dari peta percepatan batuan dasar periode pendek 1 detik (S1), untuk ketiga belas daerah terpilih pada provinsi kalimantan selatan masuk pada daerah spektrum gempa berkisar dari $0,05 \mathrm{~g}$ sampai dengan $0,1 \mathrm{~g}$. Pada tabel 3 dapat dilihat nilai Ss dan S1 pada tiga belas kabupaten/kota yang dianggap mewakili kota-kota diseluruh Kalimantan Selatan.

Tabel 3. Parameter Percepatan Respons Spektral Perioda Pendek dan Perioda 1 detik di Kalimantan Selatan

\begin{tabular}{|c|l|c|c|}
\hline NO. & \multicolumn{1}{|c|}{ KOTA } & $\boldsymbol{S}_{\boldsymbol{S}}$ & $\boldsymbol{S}_{\mathbf{1}}$ \\
\hline 1 & Banjarmasin & 0,06 & 0,05 \\
\hline 2 & Banjarbaru & 0,055 & 0,05 \\
\hline 3 & Kabupaten Tanah Laut & 0,05 & 0,05 \\
\hline 4 & Kabupaten Banjar & 0,12 & 0,06 \\
\hline 5 & Kab. Barito Kuala & 0,11 & 0,06 \\
\hline 6 & Kotabaru (Pulau Laut) & 0,14 & 0,06 \\
\hline 7 & Kab. Tapin & 0,2 & 0,07 \\
\hline 8 & Kab. Hulu Sungai Selatan & 0,25 & 0,08 \\
\hline 9 & Kab Hulu Sungai Tengah & 0,29 & 0,09 \\
\hline 10 & Kab. Kotabaru & 0,3 & 0,09 \\
\hline 11 & Kab. Hulu Sungai Utara & 0,28 & 0,09 \\
\hline 12 & Kab. Tabalong & 0,27 & 0,09 \\
\hline 13 & Pegunungan Meratus & 0,4 & 0,09 \\
\hline
\end{tabular}

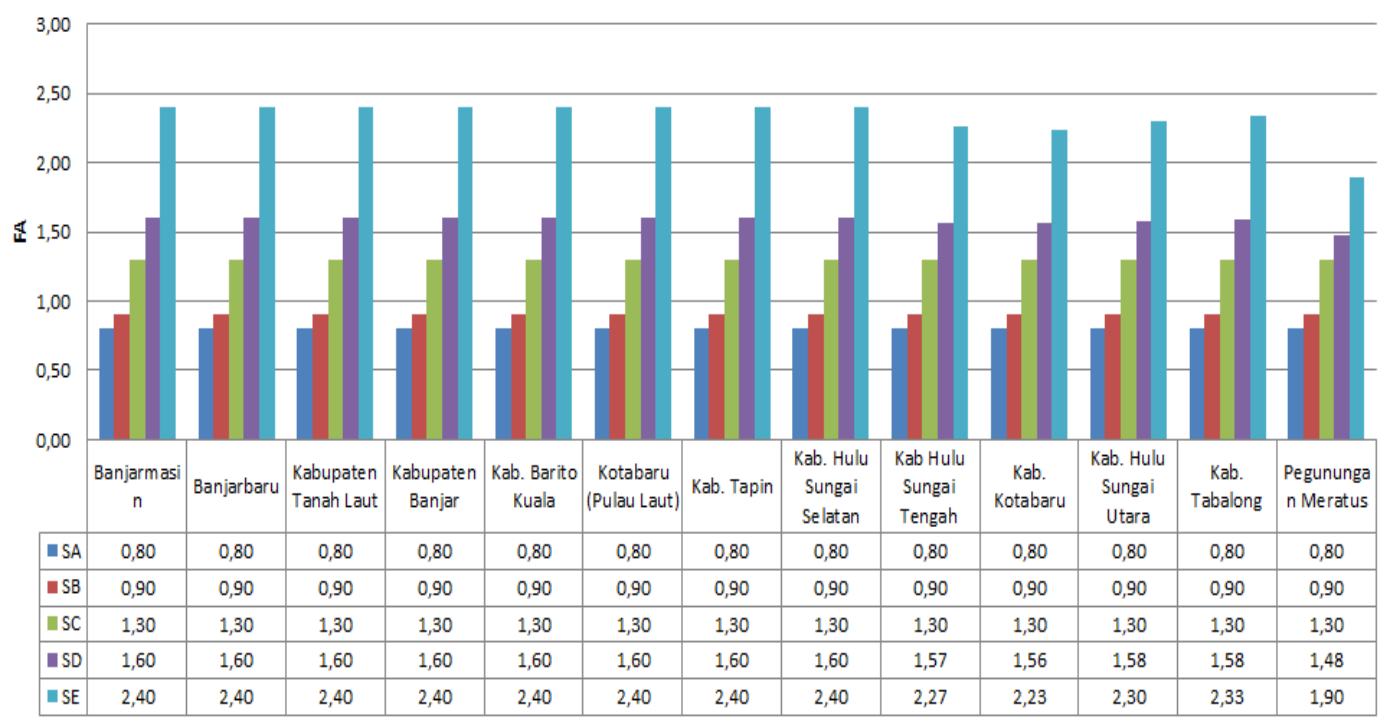

Gambar 3. Grafik Koefisien Situs $F_{A}$ berdasarkan tiap jenis Situs 


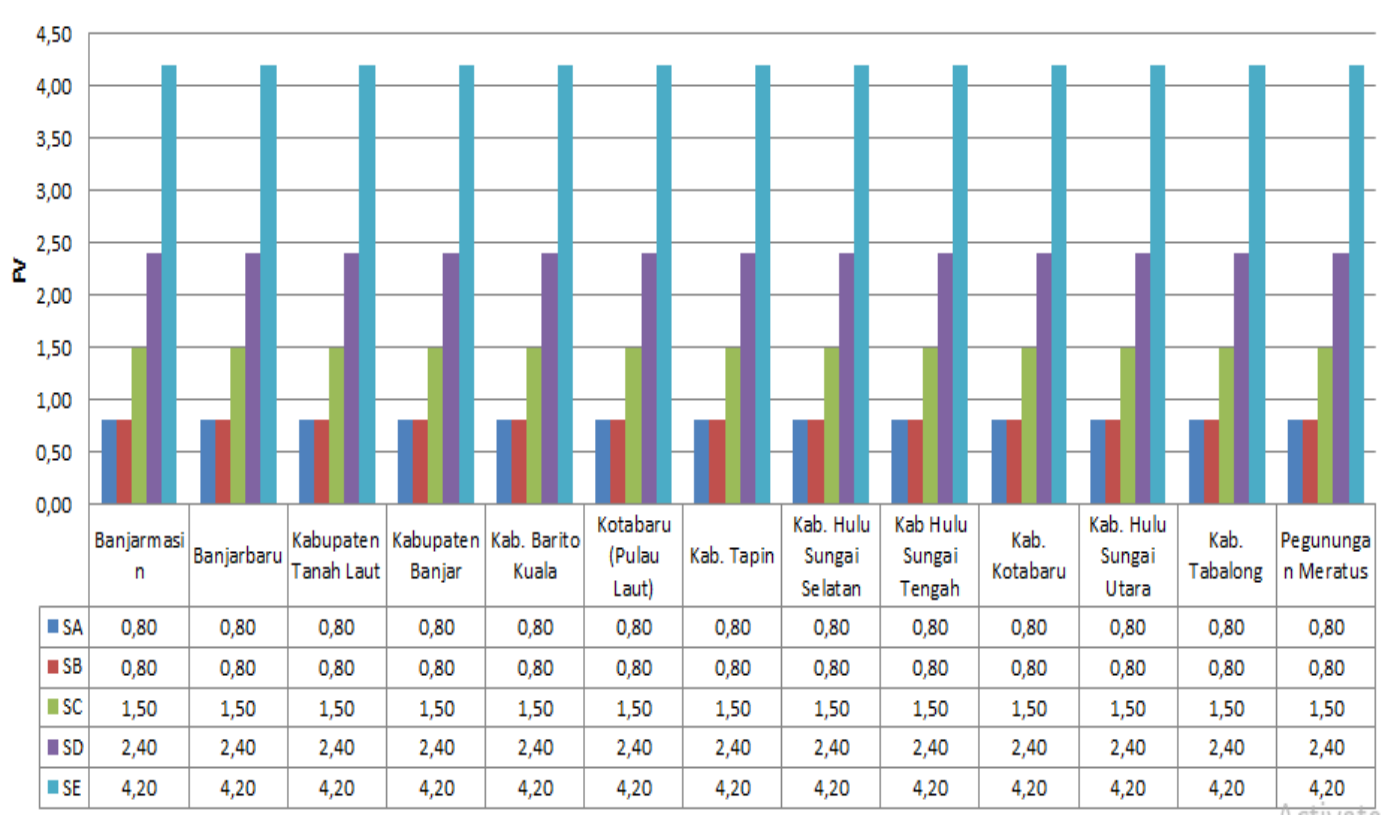

Gambar 4. Grafik Koefisien Situs Fs berdasarkan tiap jenis Situs

Dengan menggunakan nilai Fa dan F1 dari SNI 1726:2019. Maka ditentukan nilai Fa dan F1 yang dapat dilihat pada gambar 3 dan gambar 4. Nilai tersebut didapatkan dari hasil interpolasi berdasarkan nilai SS dan S1.Berikutnya perbandingan nilai spektrum respons desain untuk kategori kelas situs SA, SB, Tanah Keras (SC), Sedang (SD) dan Lunak (SE) di 13 kota/kabupaten di Kalimantan Selatan untuk perioda pendek (0.2 detik), SDs dan perioda 1-detik, $\mathrm{SD}_{1}$ dapat dilihat pada gambar 5 dan 6.

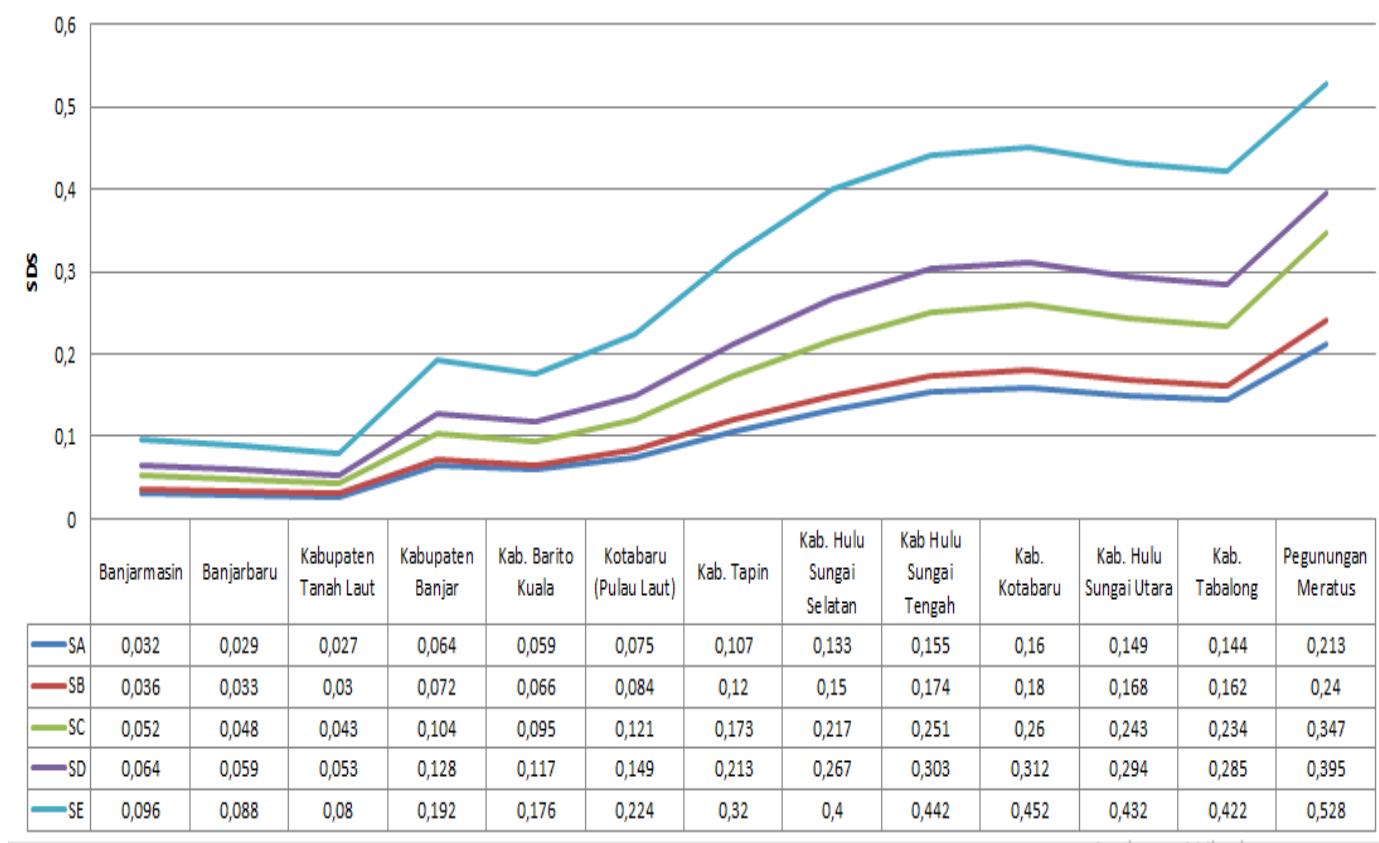

Gambar 5 . Grafik Spektrum Respons Desain Perioda Pendek $\left(S_{D S}\right)$ Berdasarkan Kelas Situs 
JURNAL KACAPURI

JURNAL KEILMUAN TEKNIK SIPIL

Volume 3 Nomor 2 Edisi Desember 2020

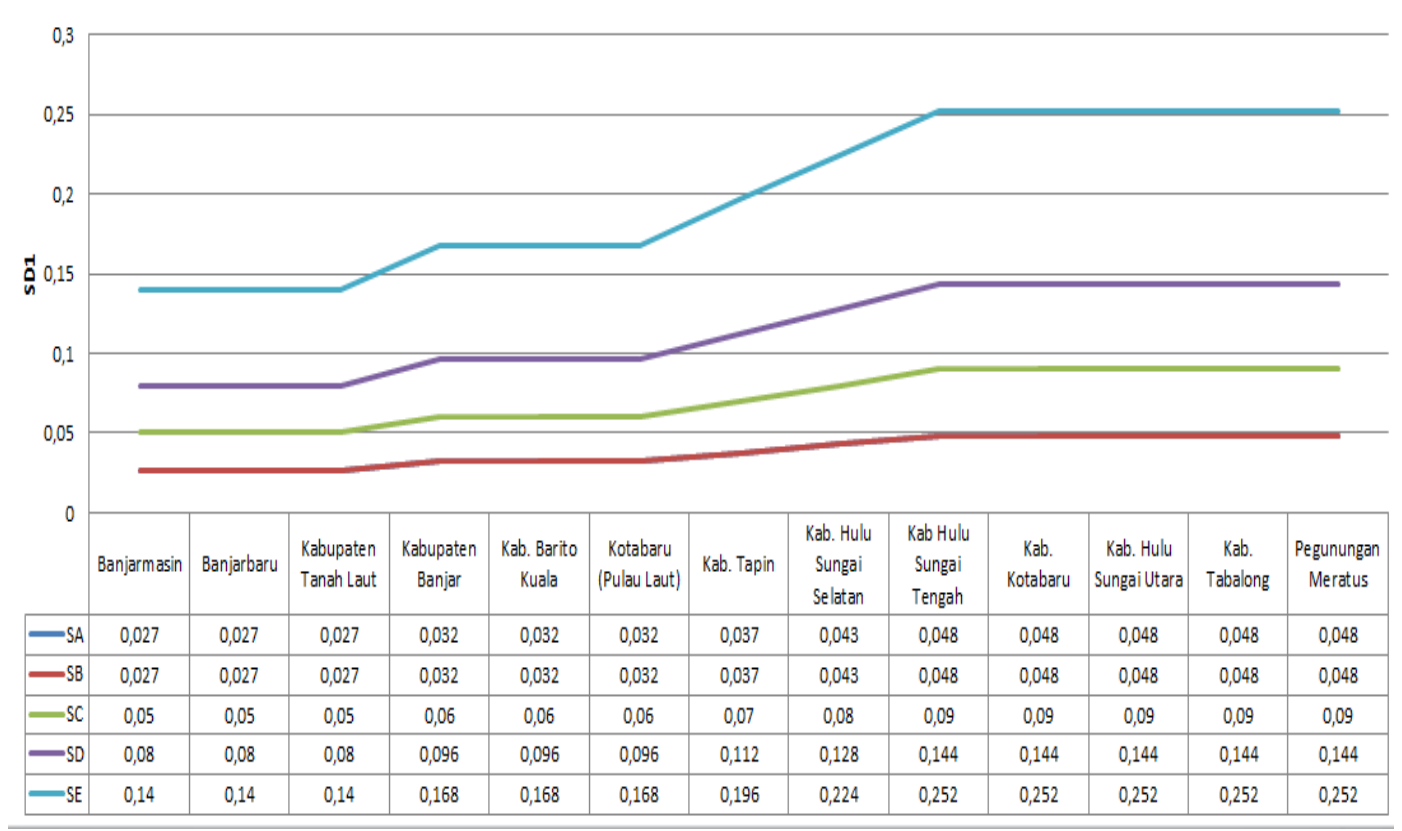

Gambar 6. Grafik Spektrum Respons Desain Perioda 1-detik $\left(S_{D 1}\right)$ Berdasarkan Kelas Situs

Semua jenis struktur akan ditentukan tingkatan Kategori Desain Seismik (KDS), yang dinyatakan dalam huruf A hingga D. Struktur dengan risiko gempa paling kecil dikategorikan ke dalam KDS A, sedangkan struktur dengan tingkat risiko gempa paling tinggi dikategorikan ke dalam KDS D. Pada tabel 4, tabel 5, tabel 6 dan tabel 7 ditunjukkan nilai KDS-nya yang ditentukan berdasarkan perbandingan KDS yang lebih tertinggi dari SDS dan SD1.

Tabel 4. Kategori Desain Seismik Bangunan Kategori Resiko I di Kalimantan Selatan

\begin{tabular}{|c|l|c|c|c|c|c|}
\hline \multirow{2}{*}{ NO. } & \multirow{2}{*}{ KOTA } & \multicolumn{5}{c|}{ KATEGORI DESAIN SEISMIK } \\
\cline { 3 - 7 } & & \multicolumn{5}{c|}{ Kategori Resiko I } \\
\cline { 2 - 7 } & & SA & SB & SC & SD & SE \\
\hline 1 & Banjarmasin & A & A & A & B & C \\
\hline 2 & Banjarbaru & A & A & A & B & C \\
\hline 3 & Kabupaten Tanah Laut & A & A & A & B & C \\
\hline 4 & Kabupaten Banjar & A & A & A & B & C \\
\hline 5 & Kab. Barito Kuala & A & A & A & B & C \\
\hline 6 & Kotabaru (Pulau Laut) & A & A & A & B & C \\
\hline 7 & Kab. Tapin & A & A & B & B & C \\
\hline 8 & Kab. Hulu Sungai Selatan & A & A & B & B & D \\
\hline 9 & Kab Hulu Sungai Tengah & A & B & B & C & D \\
\hline 10 & Kab. Kotabaru & A & B & B & C & D \\
\hline 11 & Kab. Hulu Sungai Utara & A & B & B & C & D \\
\hline 12 & Kab. Tabalong & A & A & B & C & D \\
\hline 13 & Pegunungan Meratus & B & B & C & C & D \\
\hline
\end{tabular}


JURNAL KACAPURI

JURNAL KEILMUAN TEKNIK SIPIL

Volume 3 Nomor 2 Edisi Desember 2020

Tabel 5. Kategori Desain Seismik Bangunan Kategori Resiko II di Kalimantan Selatan

\begin{tabular}{|c|l|c|c|c|c|c|}
\hline \multirow{2}{*}{ NO. } & \multirow{2}{*}{ KOTA } & \multicolumn{5}{c|}{ KATEGORI DESAIN SEISMIK } \\
\cline { 3 - 7 } & & \multicolumn{5}{c|}{ Kategori Resiko II } \\
\cline { 3 - 7 } & & SA & SB & SC & SD & SE \\
\hline 1 & Banjarmasin & A & A & A & B & C \\
\hline 2 & Banjarbaru & A & A & A & B & C \\
\hline 3 & Kabupaten Tanah Laut & A & A & A & B & C \\
\hline 4 & Kabupaten Banjar & A & A & A & B & C \\
\hline 5 & Kab. Barito Kuala & A & A & A & B & C \\
\hline 6 & Kotabaru (Pulau Laut) & A & A & A & B & C \\
\hline 7 & Kab. Tapin & A & A & B & B & C \\
\hline 8 & Kab. Hulu Sungai Selatan & A & A & B & B & D \\
\hline 9 & Kab Hulu Sungai Tengah & A & B & B & C & D \\
\hline 10 & Kab. Kotabaru & A & B & B & C & D \\
\hline 11 & Kab. Hulu Sungai Utara & A & B & B & C & D \\
\hline 12 & Kab. Tabalong & A & A & B & C & D \\
\hline 13 & Pegunungan Meratus & B & B & B & C & D \\
\hline
\end{tabular}

Tabel 6. Kategori Desain Seismik Bangunan Kategori Resiko III di Kalimantan Selatan

\begin{tabular}{|c|l|c|c|c|c|c|}
\hline \multirow{2}{*}{ NO. } & \multirow{2}{*}{ KOTA } & \multicolumn{5}{c|}{ KATEGORI DESAIN SEISMIK } \\
\cline { 3 - 7 } & & \multicolumn{5}{c|}{ Kategori Resiko III } \\
\cline { 3 - 7 } & & SA & SB & SC & SD & SE \\
\hline 1 & Banjarmasin & A & A & A & B & C \\
\hline 2 & Banjarbaru & A & A & A & B & C \\
\hline 3 & Kabupaten Tanah Laut & A & A & A & B & C \\
\hline 4 & Kabupaten Banjar & A & A & A & B & C \\
\hline 5 & Kab. Barito Kuala & A & A & A & B & C \\
\hline 6 & Kotabaru (Pulau Laut) & A & A & A & B & C \\
\hline 7 & Kab. Tapin & A & A & B & B & C \\
\hline 8 & Kab. Hulu Sungai Selatan & A & A & B & B & D \\
\hline 9 & Kab Hulu Sungai Tengah & A & B & B & C & D \\
\hline 10 & Kab. Kotabaru & A & B & B & C & D \\
\hline 11 & Kab. Hulu Sungai Utara & A & B & B & C & D \\
\hline 12 & Kab. Tabalong & A & A & B & C & D \\
\hline 13 & Pegunungan Meratus & B & B & B & C & D \\
\hline
\end{tabular}


Tabel 7. Kategori Desain Seismik Bangunan Kategori Resiko IV di Kalimantan Selatan

\begin{tabular}{|c|l|c|c|c|c|c|}
\hline \multirow{2}{*}{ NO. } & \multirow{2}{*}{ KOTA } & \multicolumn{5}{|c|}{ KATEGORI DESAIN SEISMIK } \\
\cline { 3 - 7 } & & \multicolumn{5}{|c|}{ Kategori Resiko IV } \\
\cline { 3 - 7 } & & SA & SB & SC & SD & SE \\
\hline 1 & Banjarmasin & A & A & A & C & D \\
\hline 2 & Banjarbaru & A & A & A & C & D \\
\hline 3 & Kabupaten Tanah Laut & A & A & A & C & D \\
\hline 4 & Kabupaten Banjar & A & A & A & C & D \\
\hline 5 & Kab. Barito Kuala & A & A & A & C & D \\
\hline 6 & Kotabaru (Pulau Laut) & A & A & A & C & D \\
\hline 7 & Kab. Tapin & A & A & C & C & D \\
\hline 8 & Kab. Hulu Sungai Selatan & A & A & C & C & D \\
\hline 9 & Kab Hulu Sungai Tengah & A & C & C & D & D \\
\hline 10 & Kab. Kotabaru & A & C & C & D & D \\
\hline 11 & Kab. Hulu Sungai Utara & A & C & C & D & D \\
\hline 12 & Kab. Tabalong & A & A & C & D & D \\
\hline 13 & Pegunungan Meratus & C & C & D & D & D \\
\hline
\end{tabular}

\section{PENUTUP}

Berdasarkan hasil analisis maka dapat disimpulkan bahwa:

1) Berdasarkan Percepatan Spektrum Respons 0.2 detik pada SNI 1726-2019 daerah Kalimantan Selatan termasuk dalam daerah yang memiliki percepatan spektrum 0,2 detik dari 0,05g sampai dengan 0,4g. Dimana nilai Percepatan Spektrum Respons 0.2 detik terbesar berada di daerah pegunungan meratus dan sekitarnya.

2) Berdasarkan perbandingan kategori Desain Seismik parameter percepatan respons spektral pada periode pendek dan parameter percepatan respons spektral pada periode 1 detik didapatkan daerah yang rawan terhadap gempa yaitu daerah Kalimantan Selatan yang memiliki jenis Tanah Sedang (SD) dan Tanah Lunak (SE).

3) Struktur dengan tingkat risiko terjadi gempa paling tinggi berada di daerah dengan tanah lunak yang dikategorikan ke dalam KDS D yaitu bangunan yang digunakan oleh khalayak ramai seperti rumah ibadah, kantor, fasilitas pendidikan, fasilitas kesehatan dan lain-lain. 


\section{DAFTAR PUSTAKA}

1. ASCE/SEI 7-16. Minimum Design Loads and Associated Criteria for Buildings and Other Structures, American Society of Civil Engineers, VA.

2. Irsyam, Masyhur et all. 2018. Peta Gempa, Perkembangan Dan Aplikasinya Untuk Perancangan Struktur Dan Infrastruktur Tahan Gempa Indonesia. Seminar Nasional Teknik Sipil 2018. Bandung.

3. Setiawan, A. 2016.Perancangan Struktur Beton Bertulang Berdasarkan SNI 2847:2013. Penerbit Erlangga.

4. Sengara, I Wayan. (2018). Rekayasa Kegempaan dan Mitigasi Bencana Gempa. Workshop Konstruksi Indonesia 2018. Jakarta.

5. SNI 1726:2019. Tata Cara Perencanaan Ketahanan Gempa Untuk Struktur Bangunan Gedung Dan Non Gedung, Badan Standarisasi Nasional, Jakarta.

6. Pusat Studi Gempa Nasional. 2017. Peta Sumber dan Bahaya Gempa Indonesia Tahun 2017. Pusat Litbang Perumahan dan Pemukiman, Bandung. 